\title{
Study Of Ecosystem Approach in New Towns Development in Botabek Area
}

Parino Rahardjo ${ }^{*}$, Djoko. M. Hartono ${ }^{2}$, Emirhadi Suganda ${ }^{3}$, Hadi Susilo Arifin ${ }^{4}$

${ }^{1}$ Lecturer of Urban and Regional Planning Department, Faculty of Engineering, University of Tarumanagara, Jakarta, Indonesia.

${ }^{2}$ Lecturer of Civil Engineering Department, Faculty of Engineering, University of Indonesia

${ }^{3}$ Lecturer of Architecture Department, Faculty of Engineering University of Indonesia

${ }^{4}$ Lacturer of Landscape Architecture Department, Faculty of Agriculture. Bogor Agricultural University

Within the town, Abiotic is a built environment that includes buildings, roads, pedestrians, and other elements that interact with biotics, which are living things including plants, animals, and humans. From a landscape ecological perspective, the urban structure consists of (1) a matrix, which is a collection of dominant buildings and homogeneous elements, (2) Patches are grouped as housing, urban forests, parks, lakes, and finally (3) Corridors such as roads, rivers, and pedestrians. The dominance of watertight areas over green open spaces in urban development can lead to increased temperatures and runoff. The condition of the soil structure and the steep slope of the soil can cause landslides, therefore urban development must pay attention to the natural conditions of the area being built. This research was conducted in Kota Baru, Bogor, South Tangerang, and Cikarang (Bekasi Regency). The purpose of this study is to determine the natural environment and the built environment as well as changes in the ecosystem and their consequences for the new town and its surroundings. This research uses quantitative and qualitative approaches. Analysis of landuse change uses spatial and temporal methods, while Nieuwolt's equation is used to measure comfort. This study finds comfortable environmental planning, with green open spaces such as urban forests, city parks, and bodies of water, such as lakes, as a space for interaction between fellow new city residents and people outside the new towns.

Key Words:, Landscape Ecology, Lake, River, Urban Forestry, Urban Ecosystems

\section{Introduction}

New towns that are the object of research are cities developed by private companies called developers, are the result of the conversion of the natural environment, including natural landscapes, such as plantations, rice fields, ponds or marshes, and villages. Apart from the natural environment, it was found that rural areas located in the new urban development areas have also been converted.

New Towns have always been places characterized by migration: by definition, they have no 'original' inhabitants - every resident is a migrant. As such, New Towns are the prototypical 'Arrival Cities' and have in the past been more successful than most towns in integrating migrants or 'newcomers' (INTI - International New Town Institute, 2020). "An urban decentralization strategy focused on the establishment of new towns was embraced by Chinese planning authorities to handle the urgent demands of migrants to reduce urban problems including congestion, overcrowded house ( $\mathrm{Yu}$ Ye, Akkelies van NES, 2014, p 192, 2014).

Changes in the natural environment and villages into new urban areas, resulting in changes in the hydrological cycle and changes in microclimate, loss, and reduction of species.

An ecosystem approach is a theoretical approach that helps us to frame the chaotic web of variables and relationships. The ecosystem approach has its origins in biology It has helped biologists to understand the complexity of organisms and the delicate

*Corresponding author. Tel:+062-021-5663124; Fax 5663277

E-mail address: parinor19@gmail.com-parinor@ft.untar.ac.id 
relationship between populations and their environment The essence of the approach is that it makes it possible to analyze part of a system, The ecosystem approach suggests that analytically we can distinguish subsystems that together constitute one big system. Because subsystems are smaller, i.e., they consist of fewer variables, it is easier to get to know them or to develop some understanding of the mechanisms at work within the subsystem while remaining aware of how the subsystem is influenced by the surrounding subsystems. In turn, subsystems can be split into smaller subsystems (Ellen van Bueren. et al. eds, 2013, p 3-4).

From a landscape ecological perspective, urban developments affect patch structure by changing the size, shape, interrelationship, and composition of natural patches. According to Forman \& Gordon (1986, p 11), "landscape ecology focuses on three characteristics of the landscape".

1. Structure, the spatial relationship between a typical ecosystem and other special"elements", the distribution of energy, materials, and species.

2. Functions, interactions between spatial elements, namely the flow of energy, materials, and types of ecosystem components.

3. Changes in the structure and function of ecological mosaics over time.

"The landscape structure consists of three elements, namely: (1) patch as a nonlinear surface area, different environmental features, (2) corridors in the form of narrow plots of land which are usually attached to somewhat similar patches Likewise, the Power line corridor connects open spaces and builds. the road connecting the area. (3) The matrix is the most extensive and most connected landscape element, playing a dominant role in the function of the landscape "(Forman \& Gordon, 1986, p 83, 121, 157, 1986).

development of new towns sustainable can be achieved by maintaining a balance between environmental, economic, and social.

According Odum, (1996, P 266-267), Until recently [people have] more or less taken for granted the gas exchange, water purification, nutrient cycling and other protective functions of self- maintaining ecosystems, chiefly because neither number nor environmental manipulations have been great enough to affect regional and global balances. Now of course it is painfully evident that such balances are being affected, often detrimentally. The 'one problem, one solution' approach is no longer adequate and must be replaced by some form of ecosystem analysis that con- siders [humans] as part of, not apart from, the environment.

Despite this, most urban environments contain elements that contribute positively to ecosystem processes and functions, such as areas of vegetation, maintained landscapes, lakes, and streams. Although there may be very few ecosystems that are truly unaffected by humans, and humans are inherently part of the natural world, there are some obvious and essential differences in the way that non-human-dominated (Zari. M.P. 2018, p 70)

With the provision of a minimum area of green open space in urban areas. Urban ecosystems can maintain the hydrological balance, the availability of clean air, and the

*Corresponding author. Tel:+062-021-5663124; Fax 5663277

E-mail address: parinor19@gmail.com - parinor@ft.untar.ac.id 
availability of recreation areas accessible to all residents of the new town and the community around a new town. The layout of the green open space in a new town can be centralized or spread across multiple locations. Thus, the green open space in urban areas has a role in stabilizing the town as an ecosystem of green open space, humans have the interest to maintain its sustainability because humans are part of the ecosystem. In the town, the man is a living creature that affects the urban environment, human activities in the town need a place to accommodate the activity, the greater the population, the more diverse activities, the town is increasingly complex.

The basic characteristics of each patch are simple. They vary in type (for example, ponds, dumpsites, residential developments), sizes (large, small), and shapes (square, elongated, convoluted). The corridors are wide-to-narrow, long-to-short, straight-toconvoluted, and so on. Connected-to-disconnect, extensive-to-finite, and slotted-tocontinuous matrices. the three elements described as having borders or edges are also present everywhere. The boundary can be thought of as a line. A narrow outline, usually identifiable on each side of the line, differs from the interior of the patch or matrix on each side. For example, for a forest, edge width, edge height, and linear shape along edges help control species distribution, wildlife density, soil nutrient levels, animal movement along and across edges, and seed, soil. Edges are present in objects from buildings to deserts, forests, and lakes. In short, patches, corridors, and edges are almost universal in landscapes and urban areas of all scales (Forman, Richard T. T, 2014, p 44).

The existence of the ecosystem affects the urban environment, for example, in the case of a decrease in air temperature, surface runoff reduction, provision of clean water, keeping the underground water table.

According Sarukhan \& White. Eds ( 2005). four types of service that include, 1) supporting (e.g. water and nutrient cycling), 2) provisioning (e.g. food production, fuel wood), 3) regulating (e.g. water purification, erosion control), and 4) cultural (e.g. aesthetic and spiritual values) services. Benefits arise from managed as well as natural ecosystems. According de Groot et al., (2002), Ecosystem functions can be defined as 'the capacity of natural processes and components to provide goods and services that satisfy human needs, directly or indirectly'. Using this definition, ecosystem functions are best conceived as a subset of ecological processes and ecosystem structures. Each function is the result of the natural processes of the total ecological subsystem of which it is a part. Natural processes, in turn, are the result of complex interactions between biotic (living) and abiotic (chemical and physical) components of ecosystems through the universal driving forces of matter and energy (Sandhu. H., and Wratten.S. 2013, p 4-5).

Optimizing the area of land development that is built, this area will become impermeable, while the green open field that has the capacity of infiltration is reduced resulting in an increase in runoff volume. The purpose of research in this paper is to know the natural environment and ideal environment built in the development of new towns and to know the parameters of the ecosystem.

\section{Research methods}

*Corresponding author. Tel:+062-021-5663124; Fax 5663277

E-mail address: parinor19@gmail.com-parinor@ft.untar.ac.id 
This study uses a quantitative and qualitatife approach. To analyze changes in land use and land cover, the spatial-temporal and descriptive methods are applied using satellite imagery data derived from recordings made by the National Aeronautics and Space Agency (LAPAN), 1998, 2000, 2005, 2009, 2012. To determine the convenience, the equation of Nieuwolt is used.

\section{Research Location}

The study was conducted in three new towns, namely: Sentul town in Bogor, having an area of 2,464 ha, BSD town located in South Tangerang Town having an area of 6,000 ha, and Kota Jababeka in Bekasi, having an area of 5,600 ha.

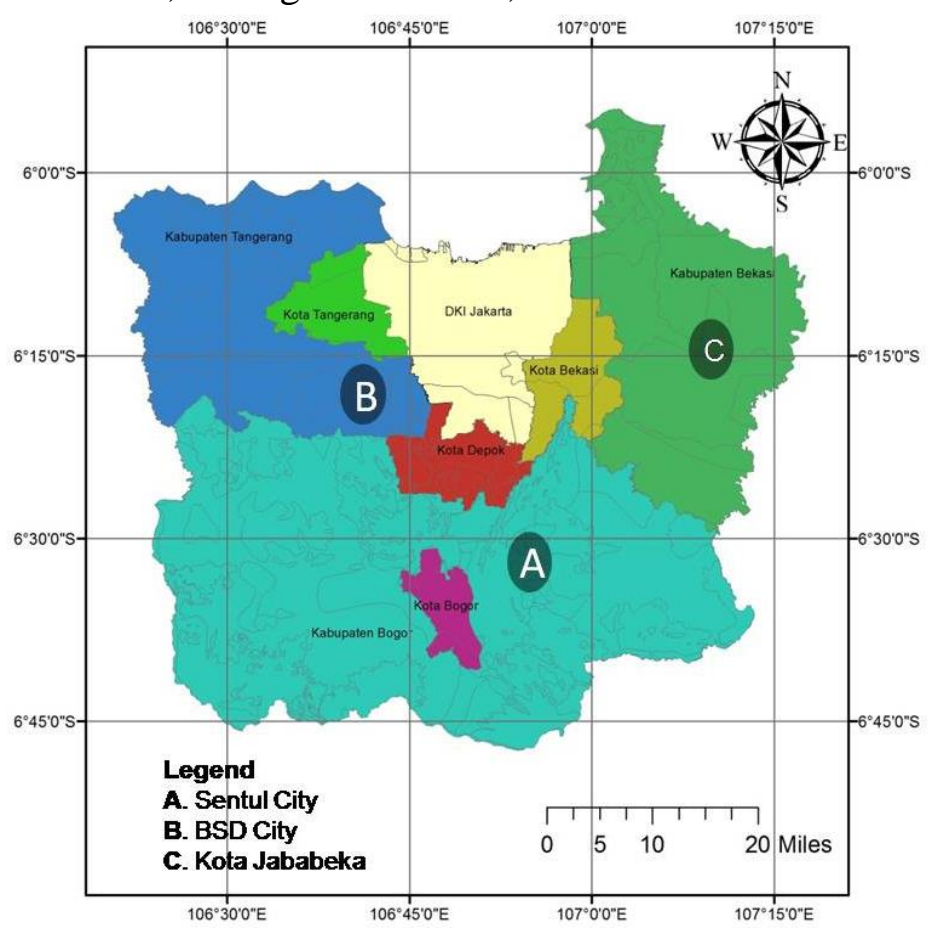

Figure 1. New Town Location

Sources: Java Administration maps, 2010

The third new town is geographically located between 6018'-6040 'South latitude and 106024'-107 012' East Longitude (figure 1). The altitude of the research objects to the sea surface is, namely: Sentul town 250-801 m above sea level, BSD town 22- $45 \mathrm{~m}$ above sea level, and Kota Jababeka $25 \mathrm{~m}$ above sea level.

New towns studied have different functions, among others: industrial cities (manufacturing) and for residential areas, municipal services, and as commercial and tourist places. The third object of this study has a different landscape with a hilly, undulating, and flat surface form.

\section{Results}

The development of Sentul town began in 1993, with a total area of 2464 ha, which is the conversion of paddy fields, plantations, and dryland agriculture. Changes in trends can be seen from the results of remote sensing, 1998, 2000, 2005, 2009, and 2012 (Figure 2). From 1998 to 2000, Sentul town development slowed down due to the economic crisis in Indonesia 
in 1998 that hit the property sector. In 2005, the Indonesian economy recovered, and this affected the development of Sentul town and increased in 2012.

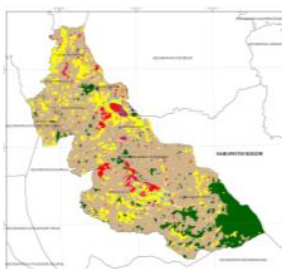

1998

Sentul town

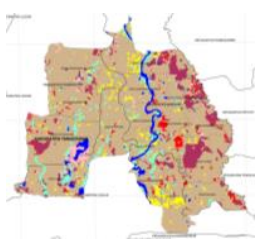

1998

BSD town

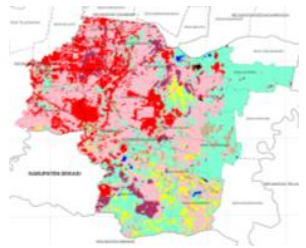

1998

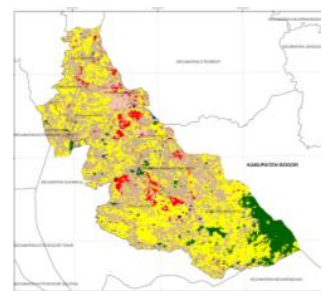

2000

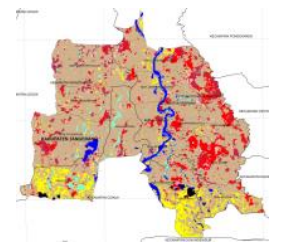

2000

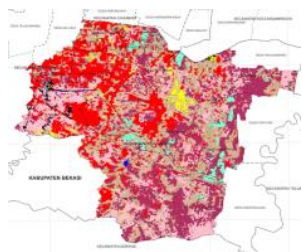

2000

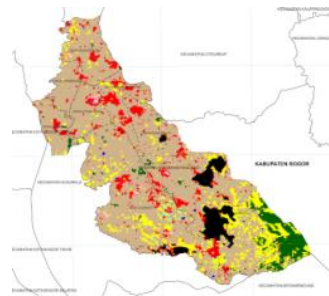

2005

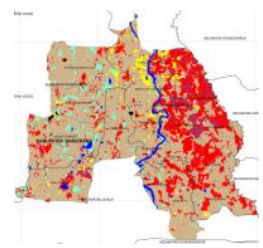

2005

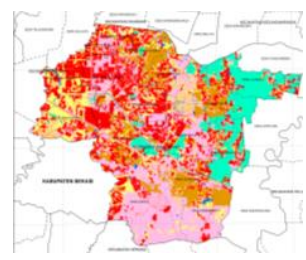

2005

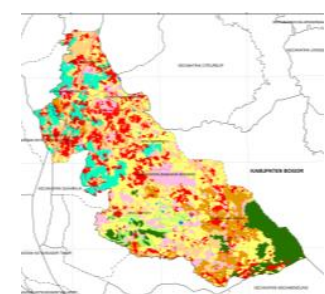

2009

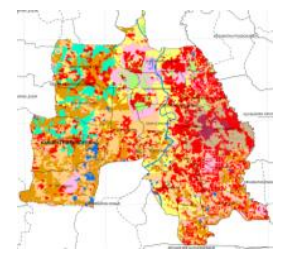

2009

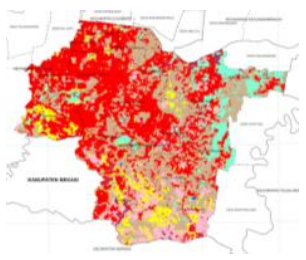

2009

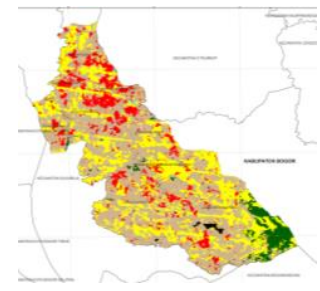

2012

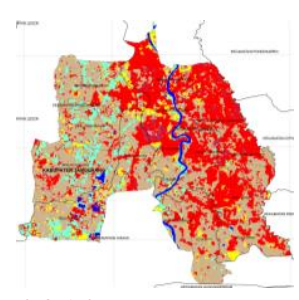

2012

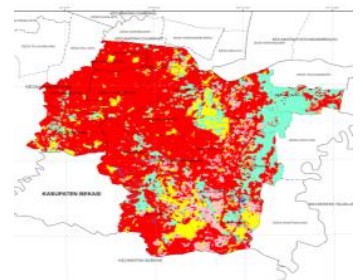

2012

Kota Jababeka
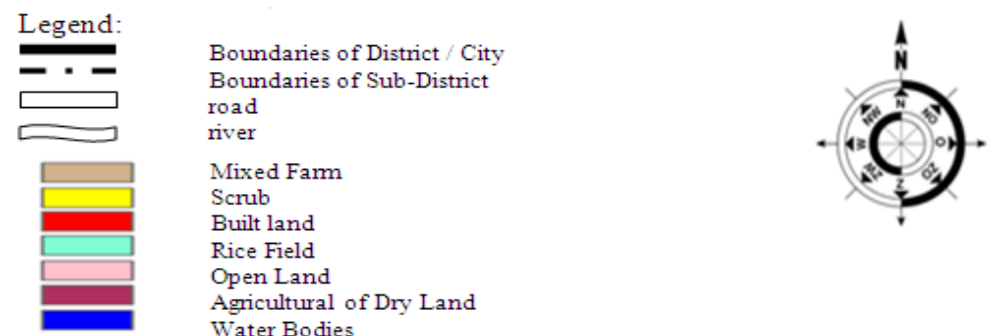

Figure 2. Changes in Land Use of the New Town Area, in 1998-2012 in Botabek

Source: Landsat

The development of BSD town from 1989-2005 was concentrated in the eastern part of Cisadane, then in 2006, it shifted to the West side of Cisadane, starting with the construction of housing and Edu town, as well as an office park. In the early stages of BSD town development, town park One (1) and town Park Two (2) were built, which were called urban forests, and during BSD development there was a change in the flow of the Jaletereng river that flows in the housing cluster.

When the Indonesian economy had not yet recovered, the Serpong Pondok Indah toll road was built and operated in 2000, this toll road was built by BSD and operated by PT Bina Marga. This toll road accelerates the construction of BSD town and changes the landscape structure in the BSD town area. The size of the water bodies has decreased in the three new towns, and this is because ponds or marshes are transformed into parks or built-up areas.

Of the three new towns, Kota Jababeka fastest land development in 2012 has reached $65 \%$ of the total area (5600 ha). Jababeka town is administratively located in North Cikarang, East Cikarang, and Cikarang Bekasi Selatan. Jababeka town Development Area started in

*Corresponding author. Tel:+062-021-5663124; Fax 5663277

E-mail address: parinor19@gmail.com - parinor@ft.untar.ac.id 
1989. Originally developed as an industrial park in Jababeka town area of 1,570 ha, then grew with the development of a residential area of 1400 ha (Public Expose PT Jababeka, 2011). Further developments increased to $+/-5,600$ ha (annual report of PT Jababeka 2012). Optimizing land-use as an industrial and residential area has an impact on the narrowness of green open space and widespread built-up area, become impermeable environments, resulting in infiltration capacity shrinking and run-off enlarged.

The conversion of plantations and villages, has an impact on the environment, resulting in changes to the landscape structure and the hydrological cycle. "Urban development by carrying out landscape conversion affects ecosystem processes, species richness, and changes in environmental physical attributes, changes in size, shape, linkages, and affects the structural composition of natural patches that cause the environment to be species-poor; Physical changes in ecosystems result in various disturbances in the landscape (Alberti, 2000)."

Table 1 Land Development Fact of the New Towns

\begin{tabular}{llll}
\hline General Condition (Development of Towns) & & Kota Jababeka \\
\hline Object & Sentul town & BSD town & 1984 \\
\hline $\begin{array}{l}\text { Development } \\
\text { Year }\end{array}$ & 1995 & 1989 & \\
\hline Function & Tourist destinations & Town of services and trade & Industrial towns \\
\hline Large & $3000 . \mathrm{Ha}$ & $6.000 \mathrm{Ha}$ & $5.600 \mathrm{Ha}$ \\
\hline $\begin{array}{l}\text { Altitude from } \\
\text { Sea Level }\end{array}$ & $250-810 \mathrm{~m}$ from sea level & $2245 \mathrm{~m}$ from sea level & $10-25 \mathrm{~m}$ from sea level \\
\hline Geohydrology & $\begin{array}{l}\text { Scarce underground water } \\
\text { Low permeability }\end{array}$ & $\begin{array}{l}\text { Underground water, there } \\
\text { Permeability good }\end{array}$ & $\begin{array}{l}\text { Underground water, there } \\
\text { Good permeability }\end{array}$ \\
\hline Land Surface & Hilly & Flat & Flat \\
\hline
\end{tabular}

The new towns that are the object of research in each town have a different altitude from sea level (Table 1) and cause differences in air temperature in each town, while the land surface conditions are different in each town affecting the pattern of site development. The flat land surface allows optimal land development and is suitable for the development of industrial estates with a gridiron pattern. The development of this model pattern can expand impermeable of land and narrow green open space so that this condition has the potential, to increase runoff. In hilly land development, development has limitations, namely on sloping land but has an attractive appearance, but on slopes $>25 \%$, it cannot be developed but is protected as the urban forest.

\section{Discussions}

The development of the new towns, which became the object of research, was originally a local people's fields, rubber plantations, rural areas, which were converted.

The land cover is defined by the attributes of the earth's land surface and immediate subsurface, including biota, soil, topography, surface and groundwater, and human structures. Land-cover conversions (i.e., the complete replacement of one cover type by another) are measured by a shift from one land-cover category to another as is the case in agricultural expansion, deforestation, or change in urban extent. Land-cover modifications are more subtle changes that affect the character of theland cover without changing its overall classification (Lambin.E.F., Geist.H.I., and Erika Lepers.E. 2003, p 213-214,).

\footnotetext{
*Corresponding author. Tel:+062-021-5663124; Fax 5663277
}

E-mail address: parinor19@gmail.com-parinor@ft.untar.ac.id 
Sentul city is in a hilly area. Slopes with a slope of $>25 \%$ are conserved, becoming urban forest. The forest area in Sentul city is about 300 ha. Meanwhile, green open space with a slope of $<25 \%$ is used as a recreation area and can be accessed by residents from around the city of Sentul. BSD is developed on flat land to hills. BSD City has 2 urban forests with an area of 2.5 ha and an area of 9 ha. Both urban forests are accessible to everyone. Apart from the two urban forests, BSD City plans to develop a 150 ha botanical garden by utilizing $7.5 \mathrm{~km}$ of riparian along the Cisadane River.

According to Forman, and Richard T.T (2014 p 44), urban ecology includes Patches, Corridors, and Matrix. In the three Kota Baru, Sentul patches are lakes, golf courses, housing and trade clusters, urban forests. The patch on the Housing cluster has an attractive edge, the row of houses on the road does not face the road, but instead has its back to the road in the form of a back yard, this can avoid changing the function of settlements into the trade. areas that often occur in settlements in other cities. City Forests in Sentul City, city forests, and city parks act as educational parks and interactions with people in new cities and people outside the new cities so that they can become recreational and educational destinations. Ecosystem services provided by city forests/city parks, namely 1) regulatory services, reducing microtemperature, and preventing soil erosion in areas with a slope of $>25 \%$. "Trees in city parks and forests can reduce heat by controlling solar radiation in four ways, including: (a) absorption, (b) reflection, (c) transmission (Robinette. Eds 1977, P: 11)". Trees in urban forests can serve to increase soil infiltration capability. Green open spaces in the form of urban forests and parks with vegetation allow for an increase in underground water reserves. Besides, urban areas with population activities that are more complex than rural areas need open space that can accommodate citizen activities, recreation, rest, and interaction, "Green Open Space is one of the providers of integrated underground water systems and water sources, open spaces, such as corridors, environmental parks and city parks that play an active role in improving urban air and water quality). "Besides, green open space in underground water storage, lakes, and ponds have the same function as rainwater storage for urban needs and as recreational areas that require open space, especially in urban areas. Besides that, it can maintain the availability of groundwater and can lower the air temperature.

The corridor in Sentul City has a large number of main roads, where the side of the road is covered with lush trees, so that it can be said to be a forest, while the middle part which borders the opposite direction is a large green open space, with a higher surface. lower than the road level so that in the event of rainwater can flow to part of the road, and can protect underground water. Main Street Kota Jababeka is similar to Sentul City in the middle of the road divider in the opposite direction there is a high voltage cable line. Another patch is the Residential cluster, with tree-lined gardens on the side of the road and house fronts that contribute to lowering temperatures and protect underground water. This pattern is found in Sentul City and BSD City, as well as foraging for wild animals such as birds. Jababeka City

Direct heating by solar radiation can raise the temperature of a building's walls and roof to $60-65^{\circ} \mathrm{C}$. Depending on the building's construction material and insulation, this can result in elevated internal temperatures. Vegetation may be used as part of a building's fabric or landscape to reduce direct heating by solar radiation. Green roofs, for example, consist of a vegetated growing medium over a waterproof membrane. Bioshade is a collective term for shade-casting pot plants and plant-draped pergolas. In both cases, they alter a building's microclimate by providing a surface for evaporative cooling and by limiting solar warming, thereby reducing internal temperatures. Wider benefits include supported biodiversity and improved air quality. They also provide

*Corresponding author. Tel:+062-021-5663124; Fax 5663277

E-mail address: parinor19@gmail.com-parinor@ft.untar.ac.id 
stormwater management, as rainfall interception and the use of permeable surfaces lead to reduced run-off to drains ( Doick and Hutchings. 2013, p 7).

Trees have a role in reducing the temperature, reducing the effect of rainwater pressure, namely a decrease in rainfall pressure before reaching the ground, due to reduced rainfall falling on the ground after penetrating the canopy so that the destructive power of the soil is reduced, and reduces runoff. In riparian corridor areas, trees have various functions ranging from controlling erosion, regulating water flow and air quality, as well as providing shade, shelter, and a source of food for wildlife and livestock (Hirokawa. 2010, p 239-240)

"Results from our study suggest that people who live in areas with higher street tree density report better health perception and fewer cardio-metabolic conditions compared with their peers living in areas with lower street tree density (Kardan.O., et.al. 2016 p 76)".

"Mahogany (Swietenia mahogani) and coffee (Coffea canephora) had the rongest roots, gmelina (Gmelina Arborea) and suren (Toona sureni) the weakest, and giant bamboo (Bambusa arundinacea) had an intermediate root strength.woody roots play a role in holding soil together and resisting mass movement in landslides (Hairiah.K. et.al. 2020 p 13)".

Urban green open spaces can be in the form of city forests, parks, roadside areas, land under high voltage channels, or parking areas in malls. This green open space can be linear. The presence of trees in the parking area outside the building creates a green open space that is shady and comfortable and protects the car from the sun. Green open spaces can lower air temperatures, and also function to accommodate runoff from surrounding areas, thereby reducing waterlogging and conserving groundwater, according to US-EEP (2003), "urban development must be able to control the volume of runoff, so that runoff has a low impact on the environment new cities ". Temperature and Humidity These three new cities prove that places with dense vegetation and shade are more comfortable than places that are open or without vegetation, in addition to reducing standing water.

Patches as a landscape structure can be in the form of settlements, trade / industrial clusters, have green open spaces with different areas, residential clusters are generally wider than industrial and trade clusters, this is because, in the industrial / trade cluster, the land is used optimally for buildings and parking areas, while in the housing cluster it is necessary to have a green open space in the form of a park as a place for recreation and interaction between residents.

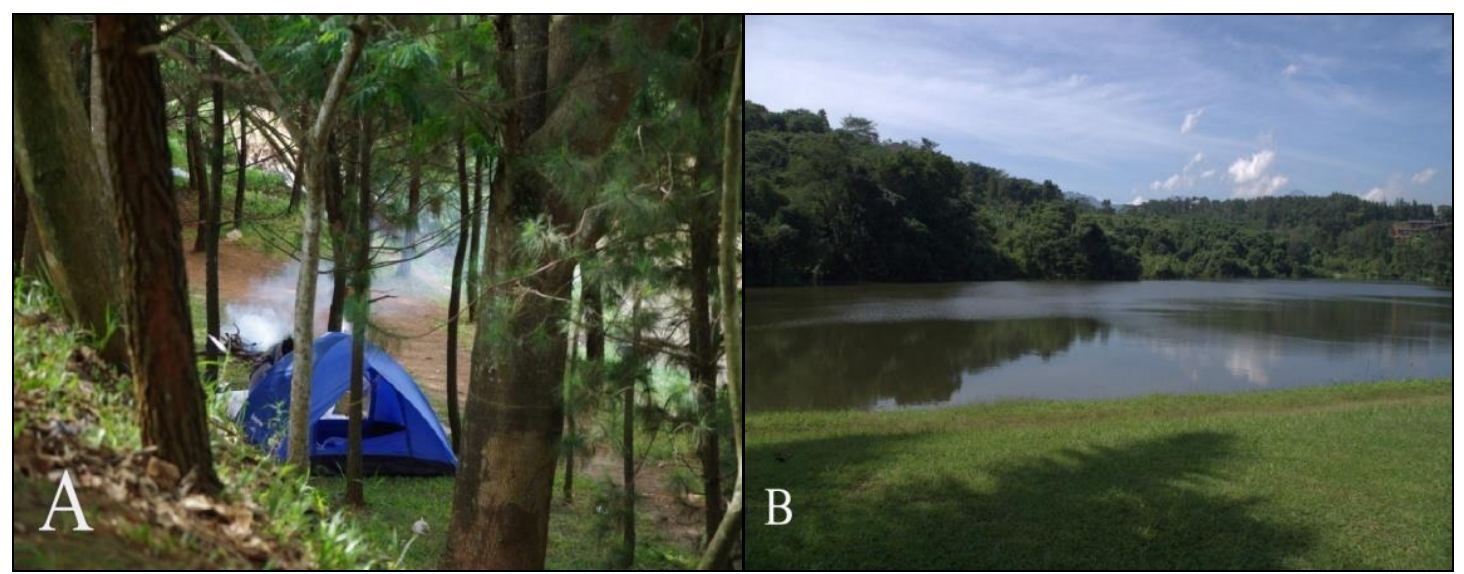

\section{Notation:}

A: Forest Town To Education \& Interaction, Recreation, and interact;

B: Lake To Education, Recreation, and Shelter

Figure 3 Patch as urban forest (Location In BSD City and lake (Location In Sentul City)

*Corresponding author. Tel:+062-021-5663124; Fax 5663277

E-mail address: parinor19@gmail.com - parinor@ft.untar.ac.id 
Patches as landscape structures, with form water bodies, such as lakes and ponds providing ecosystem services as cultural/recreation. The lake and pond in Sentul City are located in a residential cluster with an area of 2 ha while on the secondary arterial road there is a lake with an area of 0.75 ha and on the golf course found two ponds with each having an area of 0.3 ha. BSD town has a pool of 10 pieces scattered in golf courses, parks, and two resident groups with a total area of 2.6 ha. The lakes and ponds of Sentul town as well as in BSD town have social and cultural services as a place of recreation and education, in addition to the lake also has regulatory services, lowers the air temperature of the micro and can serve as a reservoir of rainwater storage, which can reduce the potential for flooding.

Indicators of comfort can be calculated using the equation of Nieuwolt (Hidayat, 2010), namely:

$\mathrm{THI}=0.8 \mathrm{t}+(\mathrm{Rh} \times \mathrm{t} / 500)$

Where:

$\mathrm{T}=$ temperature measured in degrees Celsius

$\mathrm{RH}=$ relative humidity measured by the percentage $(\%)$

The range of comfort is from mid-latitude towns and from the equation of Nieuwolt it is obtained the value of THI empirical tests on human subjects as follows:

Table 2 THI Thermal Catagories Index

\begin{tabular}{ll}
\hline $21 \leq \mathrm{THI} \leq 24$ & $100 \%$ of subjects, feeling comfortable \\
\hline $24<\mathrm{THI} \leq 26$ & $50 \%$ of subjects, feeling comfortable \\
\hline THI $>26$ & $\begin{array}{l}100 \% \text { of the subjects feeling the } \\
\text { uncomfortable heat }\end{array}$ \\
\hline
\end{tabular}

Sources: Hidayat (2010).

To find out a comfortable environment can be found by measuring the microclimate. Determination of sampling on-air and humidity measurements using purposive sampling, determined at nine sampling locations in different places in each new town, with 7 repetitions (Monday to Sunday), at hours, as follows 900AM, 1100AM, 100PM, 300PM, 500PM (Table $3)$.

Table 3 The results of measurements of temperature and humidity on the three new towns Sentul town Measurement Location

\begin{tabular}{|c|c|c|c|c|c|c|c|c|c|c|}
\hline \multirow{2}{*}{ Location } & \multirow{2}{*}{$\mathbf{C}$} & \multirow{2}{*}{ RH } & \multirow{2}{*}{ Location } & \multirow{2}{*}{$\mathbf{C}$} & \multirow{2}{*}{ RH } & \multirow{2}{*}{ Location } & \multirow{2}{*}{$\mathrm{C}$} & \multirow{2}{*}{$\mathbf{R H}$} & \multicolumn{2}{|c|}{ Average } \\
\hline & & & & & & & & & $\mathrm{C}$ & $\mathrm{Rh}$ \\
\hline 1 & 34.24 & 50 & 4 & 31.5 & 43.4 & 7 & 30.3 & 43 & \multirow{3}{*}{31.2} & \multirow{3}{*}{46} \\
\hline 2 & 30.7 & 47 & 5 & 30 & 45 & 8 & 32 & 43 & & \\
\hline 3 & 31 & 51 & 6 & 29.8 & 46 & 9 & 33.1 & 45 & & \\
\hline
\end{tabular}

BSD Measurement Location

\begin{tabular}{|c|c|c|c|c|c|c|c|c|c|c|}
\hline \multirow{2}{*}{ Location } & \multirow{2}{*}{$\mathbf{C}$} & \multirow{2}{*}{$\mathbf{R H}$} & \multirow{2}{*}{ Location } & \multirow{2}{*}{$\mathbf{C}$} & \multirow{2}{*}{ RH } & \multirow{2}{*}{ Location } & \multirow{2}{*}{$\mathrm{C}$} & \multirow{2}{*}{ RH } & \multicolumn{2}{|c|}{ Average } \\
\hline & & & & & & & & & $\mathrm{C}$ & $\mathrm{Rh}$ \\
\hline 1 & 32.5 & 41 & 4 & 32.1 & 43.4 & 7 & 32 & 43 & \multirow{3}{*}{32} & \multirow{3}{*}{44} \\
\hline 2 & 31.2 & 47 & 5 & 31.5 & 53 & 8 & 32 & 45 & & \\
\hline 3 & 31 & 41.8 & 6 & 30 & 46 & 9 & 31 & 40 & & \\
\hline
\end{tabular}

Kota Jababeka Measurement Location

\begin{tabular}{|c|c|c|c|c|c|c|c|c|c|c|}
\hline \multirow[t]{2}{*}{ Location } & \multirow[t]{2}{*}{$\mathbf{C}$} & \multirow[t]{2}{*}{ RH } & \multirow[t]{2}{*}{ Location } & \multirow[t]{2}{*}{$\mathbf{C}$} & \multirow[t]{2}{*}{ RH } & \multirow[t]{2}{*}{ Location } & \multirow[t]{2}{*}{$\mathrm{C}$} & \multirow[t]{2}{*}{$\mathbf{R H}$} & \multicolumn{2}{|c|}{ Average } \\
\hline & & & & & & & & & $\mathrm{C}$ & $\mathrm{Rh}$ \\
\hline 1 & 33 & 41 & 4 & 32.5 & 43.4 & 7 & 32 & 43 & \multirow{3}{*}{33} & \multirow{3}{*}{43} \\
\hline 2 & 32.7 & 47 & 5 & 32.7 & 53 & 8 & 33 & 39 & & \\
\hline 3 & 33 & 41.8 & 6 & 33 & 57 & 9 & 35 & 37 & & \\
\hline
\end{tabular}

Sources: Survey results

*Corresponding author. Tel:+062-021-5663124; Fax 5663277

E-mail address: parinor19@gmail.com-parinor@ft.untar.ac.id 
Based on the measurement of temperature and humidity (Table 3), it can be calculated temperature and humidity index (THI) indicating the convenience of the measured location. Based on the Nieuwolt equation, using comfort and uncomfortable zones, the comfort zone range: obtained THI > 26 results (Table 4). Sentul town as a whole has THI lower than two new towns, and this condition is possible because the geographic location of Sentul town is higher than the other two new towns (BSD town and Kota Jababeka) from the sea surface as well as premises. Wider Green Open Space with high vegetation density. The green open space area in Sentul town caused by the shape of the land surface is hilly with slopes $>25 \%$, thus limiting the development of the built area. Slope> 25\% conservation as urban forest. This conservation can maintain biodiversity, avoid landslides and increase infiltration capacity.

Table 4. Temperature and Humidity Index Microclimate of New Towns in the Botabek Region based on the Equation of Nieuwolt

Location: Sentul town

\begin{tabular}{|c|c|c|c|c|c|}
\hline Location & Results & Location & Results & Location & Results \\
\hline 1 & 28.93 & 4 & 28.40 & 7 & 26.80 \\
\hline 2 & 27.31 & 5 & 26.70 & 8 & 28.56 \\
\hline 3 & 28.10 & 6 & 26.43 & 9 & 29.70 \\
\hline \multicolumn{6}{|c|}{ Location: BSD town } \\
\hline Location & Results & Location & Results & Location & Results \\
\hline 1 & 28.67 & 4 & 28.82 & 7 & 27.50 \\
\hline 2 & 28.60 & 5 & 29.10 & 8 & 28.40 \\
\hline 3 & 28.40 & 6 & 27.80 & 9 & 30.10 \\
\hline \multicolumn{6}{|c|}{ Location: Kota Jababeka } \\
\hline Location & Results & Location & Results & Location & Results \\
\hline 1 & 29.10 & 4 & 28.82 & 7 & 28.70 \\
\hline 2 & 29.23 & 5 & 29.60 & 8 & 29.20 \\
\hline 3 & 28.70 & 6 & 30.60 & 9 & 31.10 \\
\hline
\end{tabular}

The corridors of water bodies in Sentul City are the Citeurep River and the Cikeas River. The two rivers flow in the city of Sentul with the upper reaches of the Bekasi River. The flow of these two rivers is very small, in 1992 the river discharge was $0.51 / \mathrm{sec}$ (Geology and Environmental Management, 1992). In this research, river water flow is not sufficient as a source of clean water raw water. To meet the need for clean water, Sentul City gets water supply from the Bogor Water Supply Company. The corridors of water bodies in BSD City are Cisadane River, Jaletreng River, Ciater River, and Angke River. Cisadane is a watershed upstream in the Bogor area, and downstream in the Tangerang district. The Cisadane River which flows into the city of BSD is the middle part of the Cisadane River Basin and the Cisadane River divides BSD City into two regions, East and West. Cisadane is a supplier of clean water raw materials for the city of BSD, South Tangerang City, Tangerang City, and Tangerang Regency.

The river flows Daily maximum of $412 \mathrm{~m} 3$ / second \& Minimum daily 29 M3 / second (Balai Besar Ciliwung River Basin-Cisadane, 2016). To reduce the threat of flooding in the downstream (downstream) area, the Riparian, Cisadane, and Angke Zones must be preserved, as wide as 100 meters from the riverbank are not developed as built-up areas.

The Jeletreng River provides cultural and social services, as a recreation object, among others: used as a place for recreation (camping \& playing), education, and citizen interaction. This condition is possible because the Jaletreng River flows through urban forest II and

*Corresponding author. Tel:+062-021-5663124; Fax 5663277

E-mail address: parinor19@gmail.com - parinor@ft.untar.ac.id 
cluster settlements. In the permanent cluster, the shape of the body of the Jalentreng River was modified, which was originally winding, changed to a straight line, and the Riparian area was used as a recreation area. However, the natural condition of the river body that turns straight based on the concept of river flow conservation causes a reduction in water infiltration.

\begin{tabular}{|c|c|c|c|c|c|c|c|c|c|c|c|c|c|}
\hline \multicolumn{14}{|c|}{ Ecosystem Services } \\
\hline \multirow[t]{2}{*}{ No } & \multirow[b]{2}{*}{ 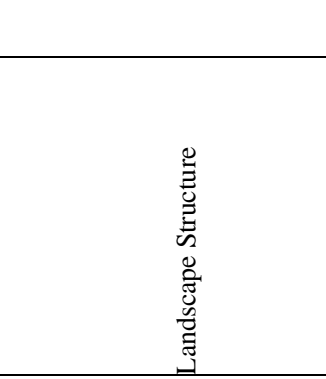 } & \multirow[b]{2}{*}{ 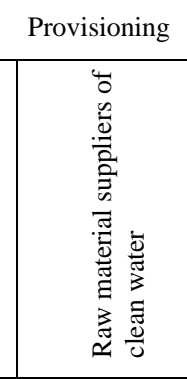 } & \multicolumn{4}{|c|}{ Regulation } & \multicolumn{3}{|c|}{ Supporting } & \multicolumn{4}{|c|}{ Cultural/Education } \\
\hline & & & 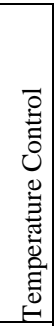 & 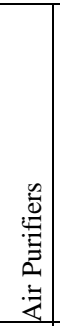 & $\begin{array}{l}0 \\
0 \\
0 \\
0 \\
0 \\
0 \\
\frac{0}{1}\end{array}$ & 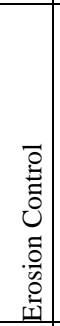 & 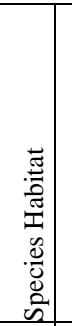 & 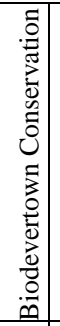 & 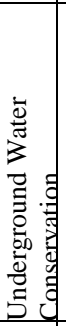 & 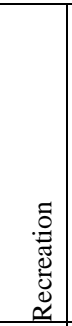 & 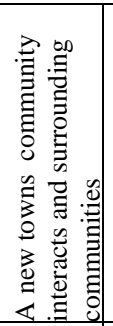 & 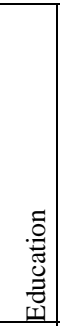 & 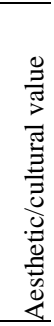 \\
\hline $\mathbf{A}$ & \multicolumn{2}{|l|}{ Corridor } & & & & & & & & & & & \\
\hline 1 & \multicolumn{2}{|l|}{ Riparian Green Open Space } & • & • & • & • & • & • & $\cdot$ & & & & \\
\hline 2 & \multicolumn{2}{|l|}{ Natural Drainage } & & & • & & • & & $\cdot$ & & & & \\
\hline 3 & \multicolumn{2}{|l|}{ River } & $\cdot$ & $\cdot$ & • & & $\cdot$ & $\cdot$ & $\cdot$ & & & & $\cdot$ \\
\hline 4 & \multicolumn{2}{|l|}{$\begin{array}{l}\text { Green Open Space Linear } \\
\text { on the Road Vehicle }\end{array}$} & $\cdot$ & $\cdot$ & $\cdot$ & & $\cdot$ & $\cdot$ & $\cdot$ & & & & \\
\hline 5 & \multicolumn{2}{|l|}{$\begin{array}{l}\text { Green Open Space Linear } \\
\text { on the Bike Path }\end{array}$} & $\cdot$ & $\cdot$ & $\cdot$ & & $\cdot$ & $\cdot$ & $\bullet$ & & - & & • \\
\hline 6 & \multicolumn{2}{|l|}{$\begin{array}{l}\text { Green Open Space Linear } \\
\text { on the Pedestrian }\end{array}$} & $\cdot$ & $\cdot$ & $\cdot$ & & $\cdot$ & $\cdot$ & $\cdot$ & & • & & • \\
\hline 7 & \multicolumn{2}{|l|}{$\begin{array}{l}\text { Green Open Space Linear } \\
\text { on the Extra voltage of Air } \\
\text { Duct }\end{array}$} & & & & & • & & $\cdot$ & & & & \\
\hline B & \multicolumn{2}{|l|}{ Patch } & & & & & & & & & & & \\
\hline 8 & \multicolumn{2}{|l|}{ Urban Forest } & $\cdot$ & $\cdot$ & $\cdot$ & $\cdot$ & $\cdot$ & $\cdot$ & $\cdot$ & $\cdot$ & $\cdot$ & $\cdot$ & $\cdot$ \\
\hline 9 & \multicolumn{2}{|l|}{ Urban Park } & $\cdot$ & $\cdot$ & $\cdot$ & $\cdot$ & $\cdot$ & $\cdot$ & $\cdot$ & $\cdot$ & $\cdot$ & $\cdot$ & $\cdot$ \\
\hline 10 & \multicolumn{2}{|l|}{ Lake/ponds } & $\cdot$ & $\cdot$ & $\cdot$ & $\cdot$ & $\cdot$ & $\cdot$ & $\cdot$ & $\cdot$ & $\cdot$ & $\cdot$ & $\cdot$ \\
\hline 11 & \multicolumn{2}{|l|}{ Housing Cluster } & & & & & \begin{tabular}{l|l}
$\cdot$ & \\
\end{tabular} & \begin{tabular}{l|l}
$\cdot$ & \\
\end{tabular} & \begin{tabular}{l|l}
$\cdot$ & \\
\end{tabular} & \begin{tabular}{l|l}
$\cdot$ \\
\end{tabular} & \begin{tabular}{l|l}
$\cdot$ & \\
\end{tabular} & $\cdot$ & $\cdot$ \\
\hline \multirow[t]{2}{*}{$\mathbf{C}$} & Matrix & \multirow{2}{*}{\multicolumn{12}{|c|}{$\begin{array}{l}\text { In Sentul City and BSD City, Green open space is the dominant element, in } \\
\text { contrast to Kota Jababeka area constructed in the form of buildings and } \\
\text { pavement, which is the dominant element }\end{array}$}} \\
\hline & Group dominant & & & & & & & & & & & & \\
\hline
\end{tabular}

Note: $\bullet$ Sign relation

Figure 4. The Landscape Structure Relationship with Ecosystem Services in New Towns Sources: Adapted from Leito \& Ahern (2002, p 72)

The ecosystem in Sentul town consists of six elements identified as (1) cluster housing, business, and trade center, (2) roads and pedestrian, (3) forest/park, (4) the lake/pond, (5) the river, and (6) natural drainage. BSD town consists of (1) cluster housing, business \& commerce, (2) body and walking trails, (3) forest/park, (4) lakes/ponds, and (5) rivers. Kota Jababeka Ecosystem is identified as (1) industrial estates, residential clusters, business and trade centers, roads and pedestrian paths, (2) urban forests, (3) ponds, and (4) rivers.

Based on the study of landscape structures, such as patches, corridors, matrices, and ecosystem services, these relationships are presented in the form of a matrix (Figure 4).

\section{Conclusion}

New urban planning must assess the natural environment, such as geomorphological conditions, vegetation, animals, and water bodies, such as rivers and lakes, and swamps to be maintained. It is necessary to have land use and management that emphasizes the 
conservation of biotic components in population systems, communities, and biodiversity (Carmel and Naveh, 2002). Maintaining biodiversity, availability of raw materials, clean water, and comfortable air are the main factors in this new city. Vegetation can lower air temperature and increase infiltration capacity.

Surface slope $>25 \%$ is not developed as an artificial environment but is maintained as an urban forest. Housing patch clusters provide services for (1) Regulating services, lowering the temperature of the microclimate; For (2) Social services such as interactions between residential residents, sports. Urban park/forest plots provide services, namely (1) Service rules (a) reduce potential runoff, (b) lower temperatures than microclimates (c) underground water conservation. (2) Social and cultural services that provide recreational services and support services for education.

Corridors in the form of rivers, provide services, including: (1) Supply services, raw water supply; (2) Regulating services, (a) As rainwater catchment areas (B) Reducing microclimate. (3) Cultural and social services, as a place of recreation.

The components of the matrix structure of the three new towns are different. The town's green open spaces in Sentul and Bumi Serpong Damai are the dominant elements, while Kota Jababeka, a group of buildings, parking lots, is the dominant element. Ecosystem parameters in developing new towns that can support new sustainable cities include (1) patches, housing groups, urban parks, urban forests, lakes/ponds, (2) Corridors in the form of green open spaces along with road vehicles, pedestrians, feet, and with soil under extra hightension cables and natural drainage.

Author Contribution: All authors contributed to the conceptualization. The following contributions were made to methodology, formal analysis, public relations; literature investigations, P.R., and D.M.H: writing - preparation of original drafts, E.S., H.S.N: writing - reviewing and editing., P.R.: project administration,. All authors have read and agree to the published version of the manuscript.

Conflicts of Interest: The authors declare no conflict of interest. The funders had no role in the design of the study; in the collection, analyses, or interpretation of data; in the writing of the manuscript, or in the decision to publish the results.

Funding: Research related to this paper received funding from the Directorate of Research and Community Service at Tarumanagara Of University.

\section{Acknowledgments}

Thanks to the National Aeronautics and Space (LAPAN), which provides satellite imagery data, and the Meteorology and Geophysics Agency (BMKG), which has been helpful in providing data of rainfall and humidity, and the interview, Mr. Ir. Pranawa, Mr. Ir. Ari Ganie, Ir Ignez.

\section{References}

Bastian. O. (2001). Landscape Ecology - towards a unified discipline?. Landscape Ecology 16: 757-766, 2001.@ 2002 Kluwer Academic Publishers. http://carmelacanzonieri.com.

Doick.K., Hutchings.T. (2013). Air temperature regulation by urban trees and green infrastructure. Forest Research. http://www.forestry.gov.uk/pdf

Ellen van Bueren. et.al.eds (2013). Sustainable Urban Environments An Ecosystem Approach. New York :Springer. DOI 10.1007/978-94-007-1294-2

*Corresponding author. Tel:+062-021-5663124; Fax 5663277

E-mail address: parinor19@gmail.com - parinor@ft.untar.ac.id 
Forman, Richard T. T.(2014). Urban ecology : science of cities. New York: Cambridge University Press

Hairiah. K. at.al (2020). Tree Roots Anchoring and Binding Soil: Reducing Landslide Risk in Indonesian Agroforestry. https://doi.org/10.3390/land9080256

Forman and Gordon (1986). Landscape Ecology. New York: John Willey \& Sons. Inc

Hirokawa, K. (2011). Sustainability and the Urban Forest: An Ecosystem Services Perspective. Natural Resources Journal. Vol. 51. < http://ssrn.com/abstract>

Hobbs. (1997). Future landscapes and the future of landscape ecology. Landscape and Urban Planning 37 (1997), p. 1-9. http://www.biol.ttu.edu/faculty/.

Jabareen, Y.R. (2006). Sustainable Urban Forms: Their Typologies, Models, and Concept. <http://jpe.sagepub.com>

Kardan.O. et.al.(2016). Neighborhood Greenspace and Health in a Large Urban Center. (In Proceeding. Urban Forests Ecosystem Services And Management. Eds. Blum. J). Mistwell Crescent: Apple Academic Press, Inc. http://www.taylorandfrancis.com

Lambin.E.F., Geist.H.I., and Erika Lepers.E. p:213-214, (2003). Dynamics Of Land-Use And Land-Cover Change In Tropical Regions. https://www.annualreviews.org/doi/pdf/10.1146/annurev.energy.28.050302.105459

Purnama. S (2008). Evaluasi Potensi Sumber Daya Air Sungai untuk Pengairan di Provinsi Jawa Barat dan Banten. JRL, Volume 5, no 1, hal 61-67. ISSN:2085-2086. http://geo.ugm.ac.id/wp-content/uploads/2013/04/

Sandhu. H., Wratten. S. (2013). Ecosystem Services in Farmland and Cities. In the Proceedings of the seminar. Wratten. S., et al. Ecosystem Services in Agricultural and Urban Landscapes. West Sussex : John Wiley \& Sons, Ltd

Robinette, Eds (1977). Landscape Planning for Energy Conservation. Reston, Virginia: Environmental Design Press.

The Editors of Encyclopaedia Britannica. New town, urbanology. https://www.britannica.com/topic/new-urbanology

Yu Ye, Akkelies van NES (2014). The spatial faws of new towns: Morphological comparison between a Chinese new and old town through the application of space syntax, spacematrix and mixed use index. Itu A|Z Vol: 11, No: 2, 191-208, 2014-2 Itu A|Z Vol: 11, No: 2, 191-208, 2014-2. https://jag.journalagent.com/itujfa/pdfs/Itujfa16362-Dossier_Articles-YE.

Zari. M. P. (2018). Regenerative Urban Design and Ecosystem Biomimicry. New York: Routledge

*Corresponding author. Tel:+062-021-5663124; Fax 5663277

E-mail address: parinor19@gmail.com - parinor@ft.untar.ac.id 